\title{
Intravenous Immunoglobulin (IVIG) in Treating Non-ventilated COVID-19 Patients with Moderate to Severe Hypoxia is Pharmacoeconomically Favorable When Appropriately Targeted
}

Matthew Poremba ${ }^{1}$, Matthew Dehner ${ }^{1}$, Alexandra Perreiter ${ }^{1}$, Ashley Semma ${ }^{1}$, Kimberly Mills ${ }^{1}$, George Sakoulas ${ }^{1,2}$

1. Sharp Memorial Hospital, 7901 Frost Street, San Diego, CA 92123

2. Collaborative to Halt Antibiotic-Resistant Microbes (CHARM), Department of Pediatrics, University of California San Diego School of Medicine, La Jolla, CA

\section{Correspondence:}

George Sakoulas, MD, UCSD School of Medicine Biomedical Research Facility II, Room 4114, 9500 Gilman Drive, Mail Code 0760, La Jolla, CA 92093-0760 Phone: (858) 534-2325; FAX: (858) 246-1868; Email: gsakoulas@health.ucsd.edu

Short Title: IVIG is a Pharmacoeconomically Favorable Therapy in COVID-19

Word Count: 2785

Abstract Word Count: 250 


\section{Abstract}

Background: Prior studies have shown that intravenous immunoglobulin (IVIG) can improve outcomes in patients with COVID-19, but the high costs of IVIG leave questions as to its pharmacoeconomic value.

Methods: The hospital costs of 2 IVIG vs. non-IVIG COVID-19 patient groups were compared. The first cohort was a case-control analysis of 10 non-ventilated moderately to severely hypoxic COVID-19 patients who received IVIG (Privigen) matched 1:2 with 20 control patients of similar age, body mass index (BMI), degree of hypoxemia, and comorbidities. The second cohort consisted of patients enrolled in a previously published randomized open-label prospective study of 14 COVID-19 patients receiving standard of care (SOC) versus 13 patients who received SOC plus IVIG (Octagam 10\%).

Results: Among the first case control population, mean total direct costs including IVIG for the treatment group was $\$ 21,982$ per IVIG-treated case versus $\$ 42,431$ per case for matched non-IVIG receiving controls, representing a net cost reduction of $\$ 20,449$ (48\%) per case. For the second (randomized) group, mean total direct costs including IVIG for the treatment group was $\$ 28,268$ per case versus $\$ 62,707$ per case for untreated controls, representing a net cost reduction of $\$ 34,439(55 \%)$ per case. $24 \%$ of the non-IVIG patients had hospital costs exceeded $\$ 80,000$, as compared to none of the IVIG patient host ( $p=0.016$, Fisher exact test).

Conclusion: When allocated to the appropriate patient type (moderate to severe illness without end-organ comorbidities and age $<70$ years), IVIG can significantly reduce hospital costs in COVID-19 care. More importantly, it may reduce the demand on scare critical care resources during the COVID-19 pandemic. 
medRxiv preprint doi: https://doi.org/10.1101/2021.09.26.21264152; this version posted September 27, 2021. The copyright holder for this

preprint (which was not certified by peer review) is the author/funder, who has granted medRxiv a license to display the preprint in perpetuity.

It is made available under a CC-BY-NC-ND 4.0 International license .

\section{Introduction}

Intravenous immunoglobulin (IVIG) has been available in most hospitals for 4 decades with broad therapeutic applications in the treatment of a variety of inflammatory, infectious, autoimmune, viral diseases, and Kawasaki disease via multifactorial mechanisms of immune modulation. Retrospective studies have shown potential benefit of IVIG treatment for COVID-19 ARDS in adults and the associated multisystem inflammatory syndrome in children (MIS-C). ${ }^{1-7}$ The benefit of IVIG may be more based on earlier timing of administration rather than on dose. ${ }^{2}$ Detailed case series have also been recently published with sufficient clinical granularity in their presentation to point to individual patient cases where very obvious benefit was seen. ${ }^{8}$

Three prospective randomized studies evaluating IVIG in COVID-19 were recently published. A randomized placebo-controlled double-blind study of 59 patients (30 IVIG, 29 placebo) was performed in Iran between May-June 2020. ${ }^{9}$ Multivariate logistic regression showed lack of IVIG receipt, along with increasing age, lower diastolic blood pressure and increased serum lactate dehydrogenase were associated with higher mortality. A second study at two hospitals in San Diego, CA (USA) was an open label randomized prospective study of 33 COVID-19 patients (16 IVIG, 17 controls) comparing standard of care ( $n=17)$ vs. standard of care plus IVIG $0.5 \mathrm{~g} / \mathrm{kg}$ daily x 3 days and showed a lower rate of progression to respiratory failure requiring mechanical ventilation in COVID-19 patients (13\%, 2/16 with IVIG vs. 41\%, 7/17 without IVIG, $p=0.12) .{ }^{10}$ While this difference did not achieve statistical significance among the collective subject cohorts, a post-hoc analysis of patients with A-a gradient $>200 \mathrm{~mm} \mathrm{Hg}$ showed statistically significant reduction in progression to mechanical ventilation, shorter duration length in the ICU and total hospital stay and improvement in 
medRxiv preprint doi: https://doi.org/10.1101/2021.09.26.21264152; this version posted September 27, 2021. The copyright holder for this preprint (which was not certified by peer review) is the author/funder, who has granted medRxiv a license to display the preprint in perpetuity. It is made available under a CC-BY-NC-ND 4.0 International license .

oxygenation ( $\mathrm{PaO} 2 / \mathrm{FiO} 2$ ) at day 7 . A third study from India administering $0.4 \mathrm{~g} / \mathrm{kg}$ daily $\times 5$ days in a randomized prospective open label format (50 IVIG, 50 controls) showed a significant reduction in hospital stay (8 vs 18 days) among IVIG recipients. ${ }^{11}$

Despite these positive results, the relatively high costs of IVIG makes its pharmacoeconomic value uncertain. Therefore, we performed an analysis of healthcare costs of hypoxic COVID-19 treated patients with IVIG compared to COVID-19 patients not given IVIG. 
medRxiv preprint doi: https://doi.org/10.1101/2021.09.26.21264152; this version posted September 27, 2021. The copyright holder for this preprint (which was not certified by peer review) is the author/funder, who has granted medRxiv a license to display the preprint in perpetuity.

It is made available under a CC-BY-NC-ND 4.0 International license .

\section{Methods}

Design: All patients in this study were hospitalized at a single site located in San Diego, California. This analysis received approval from the health system's Institutional Review Board (IRB), and was granted a waiver of subject authorization given the retrospective nature of the study. Treatment patients in both cohorts received IVIG 0.5 $\mathrm{g} / \mathrm{kg}$ adjusted body weight daily for 3 consecutive days.

Patient Cohort \#1-Retrospective Case Control: IVIG (Privigen 10\%, CSL Behring) was utilized off-label to treat moderate to severely ill non-ICU patients with COVID-19 requiring $\geq 3$ liters $\mathrm{O} 2$ by nasal cannula, not mechanically ventilated, but considered at high risk for respiratory failure. Pre-set exclusion criteria for IVIG off-label use in the treatment of COVID-19 were age $>70$, active malignancy, organ transplant recipient, renal failure, heart failure, or dementia. Controls were obtained from a list of all COVID19 patients admitted matched based to cases 2 to 1 on the bases of age (+/- 10 years), body mass index (+/- 10), gender, co-morbidities present at admission (eg. hypertension, diabetes mellitus, lung disease, or history of tobacco use) and maximum oxygen requirements within the first 48 hours of admission. In situations where more than two potential matched controls were identified for a subject, the two controls with ages closest to the treatment patient were selected. One IVIG patient was excluded because only 1 matched age control could be found. Pregnant patients who otherwise fulfilled criteria for IVIG administration were also excluded from this analysis. 
medRxiv preprint doi: https://doi.org/10.1101/2021.09.26.21264152; this version posted September 27, 2021. The copyright holder for this preprint (which was not certified by peer review) is the author/funder, who has granted medRxiv a license to display the preprint in perpetuity.

It is made available under a CC-BY-NC-ND 4.0 International license .

Patient Cohort \#2-Prospective Randomized Trial: IVIG (Octagam 10\%, Octapharma, Inc) use in COVID-19 was studied in a previously published prospective open-label randomized trial. ${ }^{10}$ This pilot trial included 16 IVIG-treated patients and 17 control patients, of which 13 and 14 patients, respectively, had hospital cost data available for analysis in this study. ${ }^{10}$ Inclusion and exclusion criteria for this trial are previously published, but most notably included COVID-19 patients requiring $\geq 4$ liters nasal cannula to maintain $\mathrm{S}_{\mathrm{a}} \mathrm{O} 2$ of $\leq 96 \%$.

Outcomes: Cost data was independently obtained from our finance team who provided us with the total direct cost and the total pharmaceutical cost associated with each admission. We also compared total length of stay (LOS) and ICU LOS between treatment arms, as these were presumed to be the major drivers of cost difference. We used the paired Wilcoxon rank sum test for our case-control group and the Fisher exact test for our prospective randomized cohort. 
medRxiv preprint doi: https://doi.org/10.1101/2021.09.26.21264152; this version posted September 27, 2021. The copyright holder for this preprint (which was not certified by peer review) is the author/funder, who has granted medRxiv a license to display the preprint in perpetuity.

It is made available under a CC-BY-NC-ND 4.0 International license .

\section{Results}

Case-Control Analysis: A total of 10 COVID-19 hypoxic patients received Privigen IVIG outside of clinical trial settings. Oxygen requirement within the first 48 hours ranged from $3 \mathrm{~L}$ via nasal cannula to requiring bi-level positive pressure airway (BiPAP) with 100\% oxygen, median age was 56 and median Charlson comorbidity index was 1. These 10 patients were matched to 2 control patients based on oxygen requirements who did not receive IVIG, yielding 20 patients with median age 58.5 years, Charlson comorbidity index of 1 (Table 1).

The mean (standard deviation, SD) total direct hospital cost per case, including IVIG and other drug cost, for the 10 IVIG-treated COVID-19 patients was $\$ 21,982$ $(4,734)$. For the control patients, direct hospital cost per case was $\$ 42,431(48,158)$, a difference of $\$ 20,449$ per case ( $p=0.6187)$. Thus, the mean IVIG hospital cost per case was reduced $48 \%$ compared to the matched control case cost. This difference was heavily driven by 4 control patients (20\%) with hospital costs $>\$ 100,000$, marked by need for ICU transfer, mechanical ventilation, and longer hospital stays. All four of these patients required ventilation during their admission. This mitigation of progression to mechanical ventilation was consistent with our previously published open-label randomized prospective IVIG, the financial assessment of which is reviewed below. While total direct cost was lower in the treatment arm, the mean drug cost for the treatment arm was $\$ 3,121.97$ greater than the mean drug cost in the control arm $(p=0.001622)$, consistent with the high cost of IVIG therapy (Table 2). 
medRxiv preprint doi: https://doi.org/10.1101/2021.09.26.21264152; this version posted September 27, 2021. The copyright holder for this

LOS information was obtained as this was thought to be a primary driver of direct costs. The average LOS in the IVIG arm was 8.4 days while the average LOS in the control arm was 13.6 days. An average difference of 5.2 days was noted between groups $(p=0.5884)$. The average ICU LOS in the IVIG arm was 0 days while the average ICU LOS in the control arm was 5.3 days. An average difference of 5.3 days was noted between groups $(p=0.04057)$. As with the differences in cost, the differences in LOS was primarily driven by the four outlier cases in our control arm, who each had a LOS $>25$ days, as well as an ICU LOS $>20$ days.

Randomized Open-Label Patient Cohort: Patient characteristics, length of stay, and receipt of mechanical ventilation for the IVIG and control patients were previously published and showed reduction in mechanical ventilation and hospital LOS with IVIG. ${ }^{10}$ Comparing the hospital cost of the IVIG patients to the control patients from this trial revealed similar results to the matched case-control analysis discussed above. Mean (SD) total direct cost, including IVIG, for the treatment group was $\$ 28,268(19,449)$ per case versus $\$ 62,707(113,563)$ per case for untreated controls. This represented a net cost reduction of $\$ 34,439$ per case, or a $55 \%$ cost reduction per case.

Combining the case-control and the randomized trial groups, yielding 23 IVIG and 34 control patients, showed median cost per case of $\$ 22,578$ (range $\$ 10,115$ $\$ 70,929$ ) and $\$ 22,645$ (range $\$ 4723-\$ 279,797$ ) for the IVIG and control groups, respectively. Cases with cost $>\$ 80,000$ were $0 / 23(0 \%)$ versus $8 / 34(24 \%)$ in the IVIG and control groups, respectively ( $p=0.016$, Fisher Exact test). 
medRxiv preprint doi: https://doi.org/10.1101/2021.09.26.21264152; this version posted September 27, 2021. The copyright holder for this preprint (which was not certified by peer review) is the author/funder, who has granted medRxiv a license to display the preprint in perpetuity.

It is made available under a CC-BY-NC-ND 4.0 International license .

Improving care while simultaneously keeping care costs below reimbursement payments received from third party payers is paramount to the financial survival of healthcare systems. IVIG appears to do this by reducing costs through reduction in progression of COVID-19 to requiring ICU care. Reimbursement amounts will vary depending on third-party payers as well as illness acuity. We compared the costs of care of our combined case-control and randomized trial cohorts to published data on average reimbursements hospitals receive for COVID-19 care from Medicaid, Medicare, and private insurance. ${ }^{12}$ The results are displayed graphically in the Figure. IVIG demonstrated reduction in cases where costs exceed reimbursement. 
medRxiv preprint doi: https://doi.org/10.1101/2021.09.26.21264152; this version posted September 27, 2021. The copyright holder for this preprint (which was not certified by peer review) is the author/funder, who has granted medRxiv a license to display the preprint in perpetuity.

It is made available under a CC-BY-NC-ND 4.0 International license .

\section{Discussion}

Supported by published literature, ${ }^{13}$ our hospital had been utilizing IVIG in the treatment of viral acute respiratory distress syndrome (ARDS) with anecdotal success prior to COVID-19. Therefore, our group moved quickly to perform a randomized openlabel pilot study of IVIG (octagam-10\%) in COVID-19, and noted significant clinical benefit that might translate into hospital cost savings. ${ }^{10}$ Over the course of the pandemic, evidence has accumulated that IVIG may play an important role in COVID-19 therapeutics, as summarized in a recent review. ${ }^{14}$ However, despite these results, the relatively high acquisition costs of IVIG raised questions as to its pharmacoeconomic value, particularly with such a high volume of COVID-19 patients with hypoxia in light of limited clinical data.

Indeed, a year and a half into the pandemic, COVID-19 therapeutics data can be summarized into either high-quality trials showing marginal benefit for some agents or low-quality trials showing greater benefit for other agents, with IVIG studies falling into the latter category. ${ }^{15}$ This phenomenon may speak to pathophysiological heterogeneity of the COVID-19 patient population. High quality trials lack the granularity to capture and single out relevant patient subsets of maximal therapeutic benefit, with those subsets diluted out by other patient types for which no benefit is seen. Meanwhile, the more granular low quality trials are criticized as underpowered and lacking general translatability to practice. Furthermore, the lower quality trials are inclusive of some of subsequently refuted data that unfortunately have been embraced by politically-driven pandemic quackery, potentially working against the unbiased interpretation of data from other small trials that may actually be meaningful. 
medRxiv preprint doi: https://doi.org/10.1101/2021.09.26.21264152; this version posted September 27, 2021. The copyright holder for this preprint (which was not certified by peer review) is the author/funder, who has granted medRxiv a license to display the preprint in perpetuity.

It is made available under a CC-BY-NC-ND 4.0 International license .

Positive results from our pilot trial resulted in off-label utilization of IVIG (Privigen) in hospitalized COVID-19 patients restricted to specific criteria. Patients had to be moderately to severely ill requiring $>3$ liters nasal cannula, show high risk of clinical deterioration based on respiratory rate and decline in respiratory status, and with underlying comorbidities (eg. hypertension, obesity, diabetes mellitus). However, older patients (>age 70) and those underlying comorbidities marked by organ failure (eg. heart failure, renal failure, dementia, receipt of organ transplant) and active malignancy, were excluded as their clinical outcome in COVID-19 may be considered less modifiable by therapeutics, while simultaneously carrying potentially higher risk of adverse events from IVIG (eg. volume overload). This patient restriction is reflected in the overall low Charlson comorbidity index (mean of 1) of the matched case-control cohorts. As anticipated, we found a net cost reduction of $\$ 20,449$ per case, or a $48 \%$ cost reduction per case among the $10 \mathrm{IVIG}$-treated patients compared to the 20 matched controls.

We then went back to the patients from the randomized prospective trial and compared costs for the 13 of 16 IVIG patients and 14 of 17 of the control patients for whom data was available. Among this group, we found net cost reduction of $\$ 34,439$ per case, or a $55 \%$ cost reduction per case. The higher costs seen in the randomized patient cohort may be due to a combination of the fact that the patients had slightly higher comorbidity indices than the case-control group (median Charlson comorbidity index of 2 in both groups) and the fact that they were treated earlier in the pandemic (May-June 2020) as opposed to the case-control group patients who were treated in November-December 2020. 
medRxiv preprint doi: https://doi.org/10.1101/2021.09.26.21264152; this version posted September 27, 2021. The copyright holder for this

It was notable that the cost savings across both groups was derived largely from the reduction in the approximately $20-25 \%$ of control patients that went on to critical illness including mechanical ventilation, extracorporeal membrane oxygenation (ECMO) and prolonged ICU stays. Indeed, 8 of 34 of control patients but none of the 23 IVIG patients generated hospital costs in excess of $\$ 100,000$, a difference that was statistically significant even for such a small sample size. Therefore, reducing these very costly outlier events in the minority of patients translated into net savings across the board.

In addition to reducing costs, reducing progression to critical illness is extremely important during heavy waves of COVID-19, when the sheer volume of patients severely strains the relative scarcity of ICU beds, mechanical ventilators, and ECMO. Therefore, reducing the need for these resources would have a vital role that cannot be measured economically.

The major limitations of this study include the small sample size and the potential lack of generalizability of these results to all hospital centers. Our group has generated considerable experience in IVIG utilization in COVID-19 and as a result, has identified a 'sweet spot' where benefit was seen clinically and economically. However, it remains to be determined if IVIG will benefit patients with greater illness severity such as those in the ICU, on mechanical ventilation, or ECMO. Furthermore, while a significant morbidity and mortality burden of COVID-19 rests in extremely elderly patients and those with end-organ comorbidities such as renal failure and heart failure, it is uncertain if their COVID-19 adverse outcomes can be improved with IVIG or other therapies. We believe such patients may limit the pharmacoeconomic value of IVIG due to their generally 
medRxiv preprint doi: https://doi.org/10.1101/2021.09.26.21264152; this version posted September 27, 2021. The copyright holder for this

poorer prognosis regardless of intervention. On the other hand, COVID-19 patients who are not that severely ill with minimal to no hypoxia generally will do well regardless of therapy and IVIG intervention may be potentially be an unnecessary treatment expense. Evidence for this was hinted in our pilot trial ${ }^{10}$ and supported in a recent meta-analysis of IVIG therapy in COVID-19. ${ }^{16}$

Several other therapeutic options with high acquisition costs have seen an increase in use during the COVID-19 pandemic despite relatively lukewarm data. Remdesivir, the first drug found to have a beneficial effect on hospitalized patients with COVID-19, is priced at $\$ 3,120$ for a complete five day treatment course in the United States. This was in line with initial pricing models from the Institute for Clinical and Economic Review (ICER) in May 2020, assuming a mortality benefit with remdesivir use. After the SOLIDARITY trial was published, which showed no mortality benefit associated with remdesivir use, ICER updated their pricing models and released a statement that the price of remdesivir was too high to align with demonstrated benefits in June $2020 .{ }^{17,18}$ More recent data demonstrates that remdesivir may be beneficial, but only if administered to patients with $\leq 6$ days of symptoms. ${ }^{19}$ However, only a minority of patients present to the hospital early enough in their illness for remdesivir to be beneficial. ${ }^{19}$

Tocilizumab, an interleukin-6 (IL-6) inhibitor, saw an increase in use during the pandemic. An $800 \mathrm{mg}$ treatment course for COVID-19 costs $\$ 3,584$. The efficacy of this treatment option came into question after the COVACTA trial failed to show a difference in clinical status or mortality in COVID-19 patients who received tocilizumab versus placebo. ${ }^{20,21} \mathrm{~A}$ more recent study pointed to a survival benefit of tocilizumab in COVID- 
medRxiv preprint doi: https://doi.org/10.1101/2021.09.26.21264152; this version posted September 27, 2021. The copyright holder for this

19 , driven by a very large sample size ( $>4000)$, yielding statistically significant but perhaps clinically insignificant effects on survival ( $31 \%$ mortality versus $35 \%$ mortality). ${ }^{22}$ This latter study points to the extremely large sample sizes required to capture statistically significant benefits of expensive interventions in COVID-19, which our data demonstrate may benefit only a fraction of patients $(20-25 \%$ of patients in the case of IVIG). A more granular clinical assessment of these other interventions is needed to be able to capture the patient subtypes where tocilizumab, remdesivir, and other therapies will be viable pharmacoeconomically in the treatment of COVID-19, or other virallymediated cases of ARDS.

In summary, while IVIG has a high drug acquisition cost, utilization of IVIG in hypoxic COVID-19 patients resulted in reduced costs per COVID-19 case by approximately $50 \%$ and a reduction in use of critical care resources. The difference was consistent between two cohorts differing in ways of patient identification (randomized trial vs. off-label use in pre-specified COVID-19 patient types), IVIG products used (Octagam 10\% vs Privigen), and time period in the pandemic (Waves 1 and 2 in May/June 2020 vs. November/December 2020). Higher costs of care of control patients was driven largely by $\sim 25 \%$ of patients that required costly hospital critical care resources, a group mitigated by IVIG. When allocated to the appropriate patient type (patients with moderate to severe but not critical illness, < age 70 without pre-existing comorbidities of end-organ failure or active cancer), IVIG can reduce hospital costs in COVID-19 care. Given that IVIG has shown potential benefit in a variety of viral illnesses, care must be taken in future viral pandemics to identify specific patient populations where IVIG has the most anticipated benefit. 
medRxiv preprint doi: https://doi.org/10.1101/2021.09.26.21264152; this version posted September 27, 2021. The copyright holder for this preprint (which was not certified by peer review) is the author/funder, who has granted medRxiv a license to display the preprint in perpetuity.

It is made available under a CC-BY-NC-ND 4.0 International license .

\section{Acknowledgements}

Author GS was a consultant for and received research funding from Octapharma, Inc.

This study was unfunded. 


\section{References}

1. Galeotti C, Kaveri SV, Bayry J. IVIG-mediated effector functions in autoimmune and inflammatory diseases. Int Immunol. 2017;29(11):491-498.

doi:10.1093/intimm/dxx039

2. Shao Z, Feng Y, Zhong L, et al. Clinical efficacy of intravenous immunoglobulin therapy in critical patients with COVID-19: a multicenter retrospective cohort study. MedRxIV 2020; doi: 10.1101/2020.04.11

3. Xie Y, Cao S, Li Q, et al. Effect of regular intravenous immunoglobulin therapy on prognosis of severe pneumonia in patients with COVID-19. J Infect 2020; doi: 10.1016/j.jinf.2020.03.044.

4. Zhou AG, Xie SM, Zhang J, et al. Short-term moderate-dose corticosteroid plus immunoglobulin effectively reverses COVID-19 patients who have failed lowdose therapy. Preprints 2020; doi: 10.20944/preprints202003.0065.v1.

5. Cao W, Liu X, Bai T, et al. High-dose intravenous immunoglobulin as a therapeutic option for deteriorating patients with coronavirus disease 2019. Open Forum Infect Dis 2020; 7; doi: 10.1093/ofid/ofaa102.

6. Verdoni L, Mazza A, Gervasoni A, et al. An outbreak of severe Kawasaki-like disease at the Italian epicentre of the SARS-CoV-2 epidemic: an observation cohort study. Lancet 2020; doi: 10.1016/S0140-6736(20)31103-X

7. Belhadjer Z, Méot M, Bajolle F, et al. Acute heart failure in multisystem inflammatory 119 syndrome in children (MIS-C) in the context of global SARSCoV-2 pandemic. Circulation 2020; 120 doi:

10.1161/CIRCULATIONAHA.120.048360. 
8. Herth FJF, Sakoulas G, Haddad F. Use of Intravenous Immunoglobulin (Privigen or Octagam) for the Treatment of COVID-19: Retrospective Case Series. Respiration. 2020;99(12):1145-1153. doi: 10.1159/000511376. Epub 2020 Dec 14. PMID: 33316806; PMCID: PMC7801971.

9. Gharebaghi N, Nejadrahim R, Mousavi SJ, Sadat-Ebrahimi SR, Hajizadeh R. The use of intravenous immunoglobulin gamma for the treatment of severe coronavirus disease 2019: a randomized placebo-controlled double-blind clinical trial. BMC Infect Dis. 2020 Oct 21;20(1):786. doi: 10.1186/s12879-020-05507-4. Erratum in: BMC Infect Dis. 2020 Nov 26;20(1):895. PMID: 33087047; PMCID: PMC7576972.

10. Sakoulas G, Geriak M, Kullar R, Greenwood KL, Habib M, Vyas A, Ghafourian M, Dintyala VNK, Haddad F. Intravenous Immunoglobulin Plus Methylprednisolone Mitigate Respiratory Morbidity in Coronavirus Disease 2019. Crit Care Explor. 2020 Nov 16;2(11):e0280. doi:

10.1097/CCE.0000000000000280. PMID: 33225306; PMCID: PMC7671875.

11. Raman RS, Bhagwan Barge V, Anil Kumar D, Dandu H, Rakesh Kartha R, Bafna V, Aravinda VT, Raghuram TC. A Phase II Safety and Efficacy Study on Prognosis of Moderate Pneumonia in Coronavirus Disease 2019 Patients With Regular Intravenous Immunoglobulin Therapy. J Infect Dis. 2021 May 20;223(9):1538-1543. doi: 10.1093/infdis/jiab098. PMID: 33585890; PMCID: PMC7928808.

12. Bazell C, Kramer M, Mraz M, Silseth S. How much are hospitals paid for inpatient COVID-19 treatment? Milliman Report, Commissioned by Gilead Sciences, Inc, 
June 2020. https://us.milliman.com/-/media/milliman/pdfs/articles/how-muchhospitals-paid-for-inpatient-covid19-treatment.ashx

13. Liu X, Cao W, Li T. High-Dose Intravenous Immunoglobulins in the Treatment of Severe Acute Viral Pneumonia: The Known Mechanisms and Clinical Effects. Front Immunol. 2020 Jul 14;11:1660. doi: 10.3389/fimmu.2020.01660. PMID: 32760407; PMCID: PMC7372093.

14. Danieli MG, Piga MA, Paladini A, Longhi E, Mezzanotte C, Moroncini G, Shoenfeld Y. Intravenous immunoglobulin as an important adjunct in prevention and therapy of coronavirus 19 disease. Scan J Immuno 2021; 00:e13101. https://doi.org/10.1111/sji.13101

15. Starshinova A, Malkova A, Zinchenko U, Kudlay D, Glushkova A, Dovgalyk I, Yablonskiy P, Shoenfeld Y. Efficacy of Different Types of Therapy for COVID-19: A Comprehensive Review. Life (Basel). 2021 Jul 27;11(8):753. doi: 10.3390/life11080753. PMID: 34440497; PMCID: PMC8400016.

16. Xiang H, Cheng X, Li Y, Luo W, Zhang Q, Peng W. Efficacy of IVIG (Intravenous Immunoglobulin) for Corona Virus Disease 2019 (COVID-19): a meta-analysis. International Immunopharmacology 2021;107732,ISSN 1567-5769, https://doi.org/10.1016/i.intimp.2021.107732.

17. ICER's second update to pricing models of remdesivir for COVID-19.

PharmacoEcon Outcomes News. 2020;867(1):2. doi:10.1007/s40274-020-7299-y 18. Pan H, Peto R, Henao-Restrepo AM, Preziosi MP, Sathiyamoorthy V, Abdool Karim Q, Alejandria MM, Hernández García C, Kieny MP, Malekzadeh R, et al. 
Repurposed antiviral drugs for Covid-19-interim WHO solidarity trial results. $N$ Engl J Med. 2021;384:497-511. DOI: 10.1056/NEJMoa2023184

19. Garcia-Vidal C, Alonso R, Camon AM, Cardozo C, Albiach L, Agüero D, Marcos MA, Ambrosioni J, Bodro M, Chumbita M, de la Mora L, Garcia-Pouton N, Dueñas G, Hernandez-Meneses M, Inciarte A, Cuesta G, Meira F, Morata L, Puerta-Alcalde P, Herrera S, Tuset M, Castro P, Prieto-Gonzalez S, AlmuedoRiera A, Mensa J, Martínez JA, Sanjuan G, Nicolas JM, Del Rio A, Muñoz J, Vila J, Garcia F, Soriano A. Impact of remdesivir according to the pre-admission symptom duration in patients with COVID-19. J Antimicrob Chemother. 2021 Sep 2:dkab321. doi: 10.1093/jac/dkab321. Epub ahead of print. PMID: 34473275 20. Golimumab (Simponi) IV: In Combination with Methotrexate (MTX) for the Treatment of Adult Patients with Moderately to Severely Active Rheumatoid Arthritis [Internet]. Ottawa (ON): Canadian Agency for Drugs and Technologies in Health; 2015 Jul. Table 1, Cost Comparison Table for Biologic Disease-Modifying Antirheumatic Drugs. Available from:

\section{https://www.ncbi.nlm.nih.gov/books/NBK349397/table/T34/}

21. Rosas IO, Bräu N, Waters M, Go RC, Hunter BD, Bhagani S, et al. Tocilizumab in hospitalized patients with severe Covid-19 pneumonia. N Engl J Med. 2021. https://doi.org/10.1056/NEJMoa2028700.

22. RECOVERY Collaborative Group. Tocilizumab in patients admitted to the hospital with COVID-19 (RECOVERY): A randomized, controlled, open label, platform trial. Lancet 2021; 397: 1637 
Table 1. Baseline Characteristics of Case-Control Cohort

\begin{tabular}{|c|c|c|}
\hline Characteristics & $\begin{array}{c}\text { IVIG Recipients } \\
(\mathbf{N}=\mathbf{1 0})\end{array}$ & $\begin{array}{c}\text { Controls } \\
\mathbf{( N = 2 0 )}\end{array}$ \\
\hline Median Age, (range) yr & $56(23-65)$ & $58.5(27-65)$ \\
\hline Median Charlson Comorbidity Index & & $1(0-3)$ \\
\hline (Range) & $1(0-3)$ & $28.7(20.3-44.4)$ \\
\hline
\end{tabular}

Table 2. Direct Cost of Case-Control Cohort

\begin{tabular}{|c|c|c|}
\hline Costs & $\begin{array}{c}\text { IVIG Recipients } \\
(\mathbf{N}=\mathbf{1 0})\end{array}$ & $\begin{array}{c}\text { Controls } \\
\mathbf{( N = 2 0 )}\end{array}$ \\
\hline Average direct costs (range), dollars & 21,982 & 42,431 \\
& $(15,264-29,178)$ & $(4,723-161,398$ \\
\hline Average Pharmaceutical costs (range), & 7,172 & 4,050 \\
dollars & $(3,908-9,066)$ & $(307-18,754)$ \\
\hline
\end{tabular}


medRxiv preprint doi: https://doi.org/10.1101/2021.09.26.21264152; this version posted September 27, 2021. The copyright holder for this preprint (which was not certified by peer review) is the author/funder, who has granted medRxiv a license to display the preprint in perpetuity.

It is made available under a CC-BY-NC-ND 4.0 International license .

\section{Figure Legend}

Costs of IVIG and control COVID-19 cases with respect to average reimbursement by

Medicaid (solid line, bottom), Medicare (dashed line, middle), and commercial insurance

(dotted line, top) obtained from reference 12. 
medRxiv preprint doi: https://doi.org/10.1101/2021.09.26.21264152; this version posted September 27, 2021. The copyright holder for this preprint (which was not certified by peer review) is the author/funder, who has granted medRxiv a license to display the preprint in perpetuity.

It is made available under a CC-BY-NC-ND 4.0 International license .

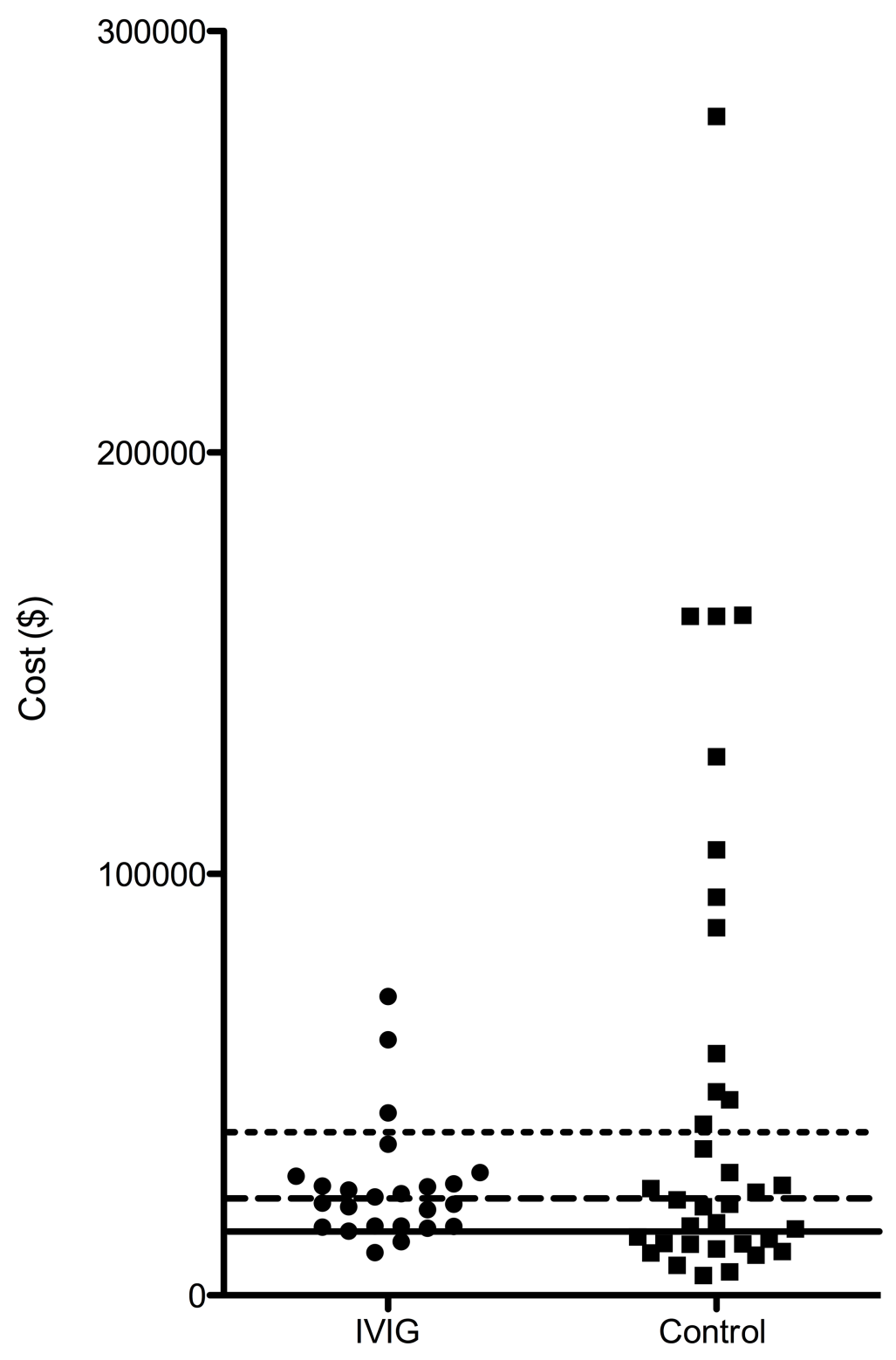

